Abstract-We investigated the use of $\delta^{13} \mathrm{C}$ and $\delta^{18} \mathrm{O}$ stable isotopes in otoliths of juvenile tainha (Mugil liza) as indicators of the stock structure of this species of mullet in the southern Atlantic Ocean. Our analysis identified 2 different spawning stocks along the Brazilian coast: the southern stock, from São Paulo $\left(25^{\circ} \mathrm{S}\right)$ to Chui $\left(33^{\circ} \mathrm{S}\right)$, with distinct seawater temperature requirements for spawning $\left(18-21^{\circ} \mathrm{C}\right)$, and the northern stock, from Rio de Janeiro $\left(23^{\circ} \mathrm{S}\right)$ to the north (up to $19^{\circ} \mathrm{S}$ ), spawning in seawater temperatures of $21-24^{\circ} \mathrm{C}$. These results will contribute to the development of appropriate stock management measures.

Manuscript submitted 13 April 2016. Manuscript accepted 6 February 2017. Fish. Bull. 115:201-205 (2017).

Online publication date: 9 March 2017. doi: $10.7755 /$ FB.115.2.7

The views and opinions expressed or implied in this article are those of the author (or authors) and do not necessarily reflect the position of the National Marine Fisheries Service, NOAA.

\title{
Stock identification of tainha (Mugil liza) by analyzing stable carbon and oxygen isotopes in otoliths
}

\author{
Valéria M. Lemos (contact author) ${ }^{1}$ \\ Cassiano Monteiro-Neto² \\ Henrique Cabral ${ }^{3}$ \\ João P. Vieira ${ }^{1}$ \\ Email address for contact author: vavadeleom@yahoo.com.br \\ 1 Instituto de Oceanografia \\ Universidade Federal do Rio Grande \\ Avenida Italia $\mathrm{km} 8$ \\ 96203-900 Rio Grande \\ Rio Grande do Sul, Brasil \\ 2 Departamento de Biologia Marinha \\ Centro de Estudos Gerais \\ Universidade Federal Fluminense \\ Outeiro de São João Batista, s/n \\ Campus do Valonguinho Centro \\ 24001-970 Niterói \\ Rio de Janeiro, Brasil \\ ${ }^{3}$ Marine and Environmental Science Centre \\ Departamento de Biologia Animal \\ Universidade de Lisboa \\ Rua Ernesto de Vasconcelos \\ 1749-016 Campo Grande \\ Lisboa, Portugal
}

The tainha (Mugil liza), also known as liza (ITIS, website), is distributed along the coast of South America, from the Caribbean Sea to Argentina (Menezes et al., 2010). The artisanal fisheries for tainha are culturally and historically important along the southern and southeastern coasts of Brazil (Vieira, 1991; CEPSUL ${ }^{1}$ ). Since the early 2000 s, this resource also has been exploited heavily by the Brazilian industrial purse-seine fishery during the reproductive spawning migration of this species

${ }^{1}$ CEPSUL (Centro de Pesquisa e Gestão dos Recursos Pesqueiros do Litoral Sudeste e Sul). 2007. I relatório de reunião técnica para o ordenamento da pesca da tainha (Mugil platanus, $M$. liza) na região sudeste/sul do Brasil, 67 p. CEPSUL, Itajaí, Brazil. [Available from website.]
(Lemos et al., 2014, 2016) because of the high value of its roe, which is considered a delicacy analogous to caviar (CEPSUL ${ }^{1}$ ). More recently, strong signs of a decline in numbers have been observed for this species, and, since 2004, tainha have been ranked as overexploited (MPA/ $\mathrm{MMA}^{2}$ ). The management plan for this species of mullet (MPA/MMA ${ }^{2}$ ) is not effective because of a total lack of basic information, including the identification and characterization of the stock or stocks of this fish (Lemos et al., 2016).

\footnotetext{
2 MPA/MMA (Ministério da pesca e aquicultura/Ministério do meio ambiente). 2015. Plano de gestão para o uso sustentável da tainha, Mugil liza Valenciennes, 1836, no sudeste e sul do Brasil, 137 p. MPA/MMA, Brasília, Brazil. [Available from website.]
} 


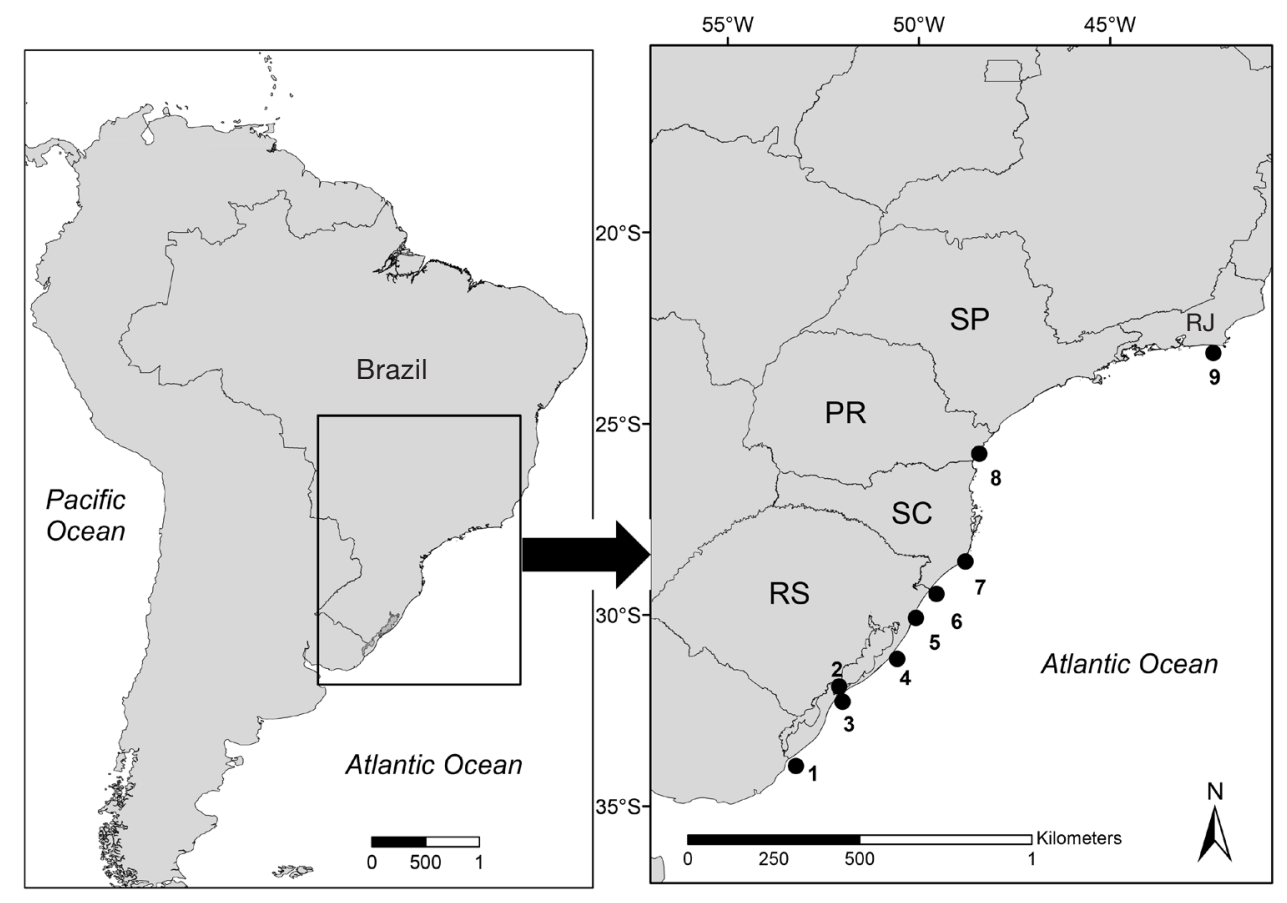

Figure 1

Map of the 9 sampling sites along the coast of southern Brazil where specimens of tainha (Mugil liza) were collected in 2011 for this study of the use of stable isotope ratios in otoliths for discrimination of stocks. Sampling sites: 1) Chuí, 2) Patos Lagoon Estuary, 3) Cassino Beach, 4) Mostardas, 5) Tramandaí, 6) Passo de Torres, 7) Laguna, 8) Pontal do Paraná, and 9) Rio de Janeiro. Abbreviations for southwest states: RJ= Rio de Janeiro, SP=São Paulo, $\mathrm{PR}=$ Paraná, $\mathrm{SC}=$ Santa Catarina, and RS=Rio Grande do Sul.

A stock of fish may consist of a single spawning unit, a biological population, a metapopulation, or various proportions of all these units (Cadrin et al., 2014). The identification of discrete units of stocks has been, for a long time, a basic requirement for fisheries science and management (Cadrin et al., 2014). Many genotypic and phenotypic methods have been applied to identify stocks and distinguish fish populations (Ihssen et al., 1981; Cadrin et al., 2014). In recent years, otolith chemistry has also been used to identify groups successfully on the basis of the characterization of environmental conditions at birth and during early life history stages (Campana et al., 1994; Gao et al., 2001).

The theoretical basis behind stock identification that is based on otolith chemistry is that otoliths are deposited at, or very close to, oxygen isotopic equilibrium with ambient seawater and thus scientists can create a record of the environmental changes that an individual fish experiences through time (Gao et al., 2005). Carbon isotopes deposited in otoliths come from dissolved inorganic carbon (DIC) and animal metabolism, reflecting the physiological status of a fish and trophic changes (Thorrold et al., 1997). The combination of carbon and oxygen isotopes is commonly used to reveal the spatial separation of fish resulting from segregation during spawning, and, therefore, can be used to define populations (Thorrold et al., 1997).
Studies of the biology of tainha along the coast of Brazil have revealed differences among populations that occur over the distribution range of the species and that results from differences in various reproductive parameters (Albieri and Araújo, 2010; GonzálezCastro et al., 2011; Lemos et al., 2014; Mai et al., 2014). For instance, Mai et al. (2014) discovered at least 2 genetically distinct populations between Rio de Janeiro, Brazil, and Mar del Plata, Argentina, that have different reproductive patterns. The southern population is distributed between Argentina and São Paulo, Brazil, and there is the gradual northward migration of tainha from Argentina (at around $37^{\circ} \mathrm{S}$ ) to Santa Catarina, Brazil (at around $26^{\circ} \mathrm{S}$ ). This migration has been reported to occur during a prespawning process that takes place in high-salinity waters (35) and at sea-surface temperatures ranging from $19^{\circ} \mathrm{C}$ to $21^{\circ} \mathrm{C}$, and peak spawning occurs in June (Lemos et al., 2014). About $95 \%$ of the commercial catch of this species occurs as fish migrate between the Rio Grande do Sul $\left(33^{\circ} \mathrm{S}\right)$ and the Santa Catarina coast $\left(26^{\circ} \mathrm{S}\right)\left(\mathrm{CEPSUL}^{1}\right)$.

A traditional and still widely held view regarding stock identification is that fish stocks are reproductively isolated and their own internal dynamics can be identified by genetic markers of lineage (Ihssen et al., 1981). But, the lack of a global molecular marker that identifies a reproductive isolation of fish (Waples et al., 


\section{Table 1}

Sites in southern Brazil where juvenile tainha (Mugil liza) were sampled in 2011, the number of fish sampled at each site $(n)$, and the mean values of the stable isotopes ratios $\left(\delta^{13} \mathrm{C}, \delta^{18} \mathrm{O}\right)$, salinity (Sal.), total length (TL), and total weight (TW) of the fish sampled at each site. Standard deviations are given in parentheses.

\begin{tabular}{|c|c|c|c|c|c|c|c|}
\hline \multicolumn{2}{|c|}{ Sites } & \multirow{2}{*}{$\frac{n}{15}$} & \multirow{2}{*}{$\frac{\delta^{13} \mathrm{C}(\% \circ)}{-6.716(0.71)}$} & \multirow{2}{*}{$\frac{\delta^{18} \mathrm{O}(\% \circ)}{0.509(0.16)}$} & \multirow{2}{*}{$\begin{array}{l}\text { Sal. } \\
28.5\end{array}$} & \multirow{2}{*}{$\frac{\mathrm{TL}(\mathrm{mm})}{28.2(0.88)}$} & \multirow{2}{*}{$\frac{\mathrm{TW}(\mathrm{g})}{0.232(0.03)}$} \\
\hline 1 & Chuí & & & & & & \\
\hline 2 & Patos Lagoon Estuary & 16 & $-6.793(0.30)$ & $0.306(0.20)$ & 7.5 & $29.5(0.89)$ & $0.284(0.02)$ \\
\hline 3 & Cassino Beach & 18 & $-6.709(0.30)$ & $0.451(0.23)$ & 27.9 & $28.6(1.09)$ & $0.200(0.01)$ \\
\hline 4 & Mostardas & 11 & $-7.057(0.26)$ & $0.383(0.16)$ & 29.1 & $28.0(1.01)$ & $0.209(0.02)$ \\
\hline 5 & Tramandaí & 6 & $-6.774(0.43)$ & $0.385(0.13)$ & 30.2 & $28.3(1.21)$ & $0.213(0.03)$ \\
\hline 6 & Passo de Torres & 15 & $-7.169(0.47)$ & $0.361(0.18)$ & 11.0 & $28.0(1.19)$ & $0.248(0.03)$ \\
\hline 7 & Laguna & 13 & $-7.323(0.16)$ & $0.261(0.11)$ & 31.1 & $28.0(0.86)$ & $0.221(0.09)$ \\
\hline 8 & Pontal do Paraná & 3 & $-7.209(0.62)$ & $0.320(0.22)$ & 30.0 & $28.3(0.57)$ & $0.270(0.05)$ \\
\hline 9 & Rio de Janeiro & 7 & $-3.754(0.51)$ & $-1.141(0.20)$ & 30.0 & $28.1(0.69)$ & $0.217(0.02)$ \\
\hline
\end{tabular}

2008) has led to an approach to identifying stocks and population units that is interdisciplinary. These integrated approaches can provide strong evidences for the identification and delineation of fish stocks (Cadrin et al., 2014). Chemical analysis, for example, provides a greater refinement than genetic analysis alone for identifying a stock (Campana and Thorrold, 2001; Cadrin et al., 2014), and the combination of both approaches is encouraged (Campana et al., 1994; Cadrin et al., 2014).

Our aim was to use isotopic analysis of $\delta^{18} \mathrm{O}$ and $\delta^{13} \mathrm{C}$ carbonate from otoliths of juvenile fish to test the hypothesis that there is a single stock of tainha within the area where $95 \%$ of the commercial catch of this species occurs in southern Brazil.

\section{Materials and methods}

Specimens were collected between June and October 2011 at 9 sites along the southern Brazilian coast (Fig. 1) after the reproductive period. One sampling was performed at each of these sites. A beach seine net (9 $\mathrm{m}$ long; $1.5 \mathrm{~m}$ high) with $13-\mathrm{mm}$ stretch mesh in the wings and $5-\mathrm{mm}$ stretch mesh in the center $3-\mathrm{m}$ section was pulled perpendicular to the beach. Salinity was measured at each sampling site. All fish caught were transported on ice to the laboratory. Individual fish were identified and weighed (in grams), and their total length (TL, in millimeters) was measured.

Differences in the lengths and weights of individuals between the 9 sampling sites were tested by using an analysis of variance (ANOVA). All fish were youngof-the-year ranging in size between 27 and $31 \mathrm{~mm}$ TL. Pairs of sagittal otoliths (right and left) were removed from each specimen and sent to the Instituto de Geociências da Universidade de Brasília for analysis. Both whole otoliths were ground to a fine powder, and isotopic ratio mass spectrometry was used for isotopic analysis of carbonates with Vienna Pee Dee Belemnite limestone as the standard.
Differences in the isotopic values among sampled sites were tested by using ANOVA. Isotope values are described by using the standard " $\delta$ per thousand (\%o)" notation defined as

$$
\delta(\%)=\left(R_{\text {sample }} \mid R_{\text {standard }}-1\right) \times 1000,
$$

where $R={ }^{18} \mathrm{O} /{ }^{16} \mathrm{O}$ or ${ }^{13} \mathrm{C} /{ }^{12} \mathrm{C}$.

\section{Results and discussion}

The values of $\delta^{18} \mathrm{O}$ and $\delta^{13} \mathrm{C}$ (from -2 to $+4 \%$ and from -9 to $+1 \%$, respectively) found in the otoliths of tainha $(n=104)$ (Table 1) were within the expected ranges for marine species (Kalish, 1991). The isotopic values of the carbon and oxygen revealed 2 groups and therefore the existence of at least 2 stocks (rather than the single stock that we had hypothesized) that have 2 environmentally distinct spawning areas within the overall study area. One group, representing samples taken between the states of Paraná and Rio Grande do Sul, constitutes the southern stock: $0.381 \%$ (standard error [SE] 0.10) and $-6.936 \%$ (SE 0.46), respectively for $\delta^{18} \mathrm{O}$ and $\delta^{13} \mathrm{C}$. The second group comprised individuals hatched in the north near Rio de Janeiro: $-1.141 \%$ ( $\mathrm{SE}$ 0.20 ) and $-3.754 \%$ (SE 0.51 ), respectively for $\delta^{18} \mathrm{O}$ and $\delta^{13} \mathrm{C}$.

The values of $\delta^{18} \mathrm{O}$ and $\delta^{13} \mathrm{C}$ from Rio de Janeiro and the southern states differed significantly (ANOVA: $23.92[P<0.0001$ and $20.45(P<0.00001)$, respectively) (Fig. 2). Homogeneity among values of $\delta^{18} \mathrm{O}$ and $\delta^{13} \mathrm{C}$ in the samples from the southern states indicates that all individuals from this area were hatched in waters with the same, or very similar, temperatures. Results from analysis indicated an inverse relationship between the environmental temperature and values of otolith $\delta^{18} \mathrm{O}$ (Kalish, 1991; Thorrold et al., 1997), revealing that southern individuals were hatched in cooler waters than those waters inhabited by individuals from Rio de Janeiro. On the basis of the relationship proposed 


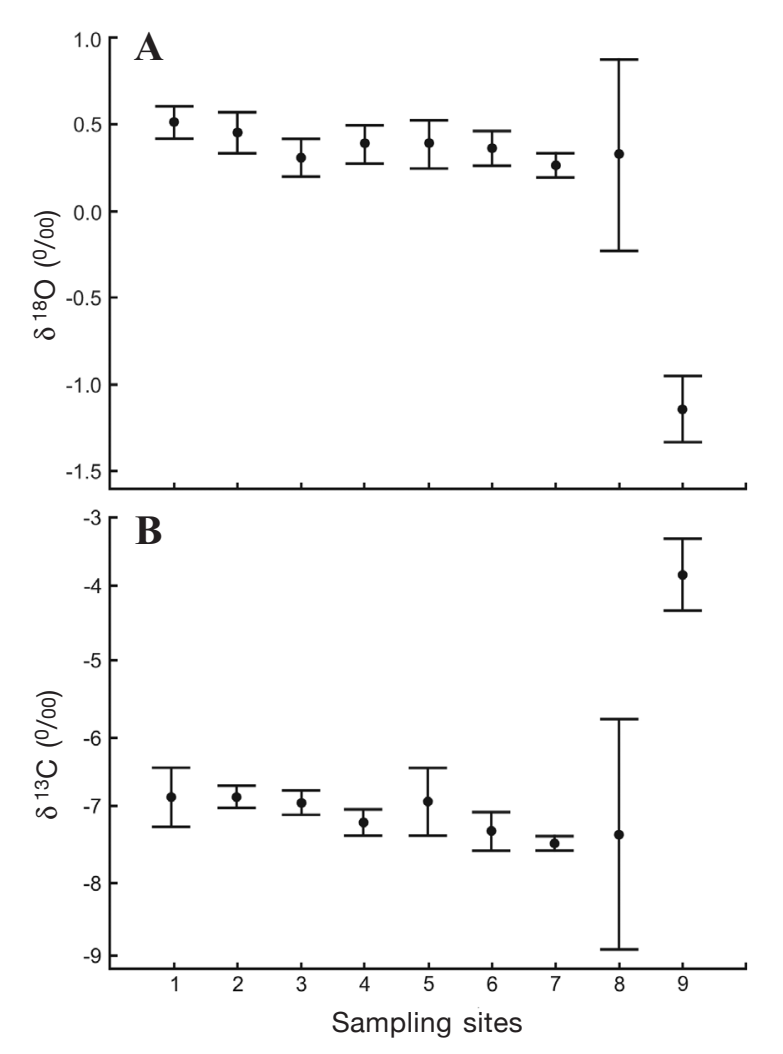

Figure 2

Mean values of $(\mathbf{A}) \delta^{18} \mathrm{O}$ and $(\mathbf{B}) \delta^{13} \mathrm{C}$ of otolith carbonate from tainha (Mugil liza) collected at 9 sampling sites: 1) Chuí, 2) Patos Lagoon Estuary, 3) Cassino Beach, 4) Mostardas, 5) Tramandaí, 6) Passo de Torres, 7) Laguna, 8) Pontal do Paraná, and 9) Rio de Janeiro. Error bars indicate standard errors.

by Kalish (1991), $\delta^{18} \mathrm{O}$ values from otoliths $(-1.141 \%$ o [SE 0.20]) corresponded with water temperature values of $21-24^{\circ} \mathrm{C}$, matching the observed sea-surface temperature of the waters off Rio de Janeiro. Similarly, $\delta^{18} \mathrm{O}$ values of the otoliths $(0.381 \%$ o [SE 0.10$])$ from southern samples corresponded with water temperature values of $18-21^{\circ} \mathrm{C}$, matching the sea-surface temperature at the hatching location of tainha as reported by Lemos et al. (2014).

Lemos et al. (2014) suggested that the peak spawning of the southern population of tainha occurs in June off the coast of the states of Santa Catarina and Paraná. According to our results, this reproductive event provides the annual supply of juveniles of tainha for the entire southern stock. Young-of-the-year disperse southward and are distributed among different nursery areas along the southern coast of Brazil. Vieira (1991) has described the process of dispersion of juvenile tainha along the coast.

The correlation of $\delta^{13} \mathrm{C}$ between $\delta^{18} \mathrm{O}$ in biological carbonates may indicate kinetic and metabolic ef- fects (McConnaughey, 1989). In otoliths, the correlation between $\delta^{18} \mathrm{O}$ and $\delta^{13} \mathrm{C}$ is not entirely dominated by kinetic effects, such as it is in corals (Devereux, 1967; Kalish, 1991; Gao and Beamish, 2003). This correlation is induced by biological fractionation and may exhibit different relationships (Gao et al., 2005; Deutsche and Berth, 2006). In contrast to $\delta^{18} \mathrm{O}, \delta^{13} \mathrm{C}$ from otoliths are not in equilibrium with $\delta^{13} \mathrm{C}$ values of sea water (Kalish, 1991). About $30 \%$ of aragonite carbon is derived from metabolism and is directly related to changes in diet (Kalish, 1991; Gao et al., 2001). The remaining $70 \%$ of aragonite carbon comes from DIC (Kalish, 1991). The isotope ratio of otolith carbonate is a mixture of these 2 fractions; therefore, the interpretation of $\delta^{13} \mathrm{C}$ is not as straight forward as it is for $\delta^{18} \mathrm{O}$ (Kalish, 1991).

As with most species of mullets, for tainha, the ingestion of diatoms and the presence of inorganic sediment in the stomach starts at about $30 \mathrm{~mm}$ TL, when juveniles begin to feed near the bottom at the surf zone (Vieira, 1991). There were no significant differences (ANOVA: $P>0.05$ ) in sizes and weights of individuals among sites (Table 1 ) that could represent differences in metabolic rates (Campana, 1999). Most of the $\delta^{13} \mathrm{C}$ incorporated into the otolith is derived from DIC (Kalish, 1991). The $\delta^{13} \mathrm{C}_{\mathrm{DIC}}$ may be subjected to small isotopic variations at different latitudes and in different water masses (Kroopnick, 1980; Thorrold et al., 1997). For instance, $\delta^{13} \mathrm{C}_{\text {DIC }}$ values in the open ocean are fairly uniform, around 1\%o; however, in environments with variable freshwater input, $\delta^{13} \mathrm{C}_{\text {DIC }}$ may vary from -5 to $-10 \%$ (Michener and Lajtha, 2007). The $\delta^{13} \mathrm{C}$ values found in our otolith samples (Fig. 2B) indicate that southern waters were influenced by estuarine inputs more than waters near Rio de Janeiro.

Genetic markers provide an important tool for identifying the degree of reproductive isolation between groups (Cadrin et al., 2014). Nevertheless, the study of the life history of an individual fish through otolith chemistry provides fine-scale geographic differences that genetic studies may not be able to detect (Conover, 1998). In our study, there was a great advantage in using phenotypic methods, such as isotope analysis of otoliths, for identifying stocks of tainha. Because the growth patterns of fish groups can be different and strongly influenced by the environment (Campana and Thorrold, 2001) and because fishing acts as a source of recent pressure on evolution (Rijnsdorp, 1993), phenotypic methods are relevant and useful in analyses of fish resources.

Isotopic analysis of $\delta^{18} \mathrm{O}$ and $\delta^{13} \mathrm{C}$ in otoliths of juvenile tainha revealed 2 stocks along the southern and southeastern Brazilian coasts. The results from this study confirm the observation of Mai et al. (2014) and provide a first biological explanation for the maintenance of genetic difference between these 2 populations. Considering the economic importance of this species for the southern coast of Brazil (from $33^{\circ} \mathrm{S}$ to $26^{\circ} \mathrm{S}$ ), managers should consider the southern stock as a distinct unit for management purposes. 


\section{Acknowledgments}

We recognize the financial aid and logistical support provided by the Universidade Federal do Rio Grande, Coordenação de Aperfeiçoamento de Pessoal de Nível Superior (CAPES), under grant CAPES/PVE N ${ }^{\circ} 71 / 2013$ and by the Conselho Nacional de Desenvolvimento Científico e Tecnológico $(\mathrm{CNPq})$ and Ministério da Pesca e Aquicultura (MPA) under grant CNPq/MPA $\mathrm{N}^{\circ} 42 / 2012$. We acknowledge the Giovanni online data system developed and maintained by the NASA Goddard Earth Science and Information Services Center. C. Monteiro-Neto and J. Vieira were recipients of a research productivity fellowship from CNPq.

\section{Literature cited}

Albieri, R. J., and F. G. Araújo.

2010. Reproductive biology of the mullet Mugil liza (Teleostei: Mugilidae) in a tropical Brazilian bay. Zoologia 27:331-340. Article

Cadrin, S. X., L. A. Kerr, and S. Mariani (eds.).

2014. Stock identification methods: applications in fishery science, $2^{\text {nd }}$ ed., 566 p. Elsevier Academic Press, London.

Campana, S. E.

1999. Chemistry and composition of fish otoliths: pathways, mechanisms and applications. Mar. Ecol. Prog. Ser. 188:263-297. Article

Campana, S. E., and S. R. Thorrold.

2001. Otoliths, increments, and elements: keys to a comprehensive understanding of fish populations? Can. J. Fish. Aquat. Sci. 58:30-38. Article

Campana, S. E., A. J. Fowler, and C. M. Jones.

1994. Otolith elemental fingerprinting for stock identification of Atlantic cod (Gadus morhua) using laser ablation ICPMS. Can. J. Fish. Aquat. Sci. 51:1942-1950. Article

Conover, D. O.

1998. Local adaptation in marine fishes: evidence and implications for stock enhancement. Bull. Mar. Sci. 62:477-493

Deutsch, B., and U. Berth.

2006. Differentiation of western and eastern Baltic Sea cod stocks (Gadus morhua) by means of stable isotope ratios in muscles and otoliths. J. Appl. Ichthyol. 22:538-539. Article

Devereux, I.

1967. Temperature measurements from oxygen isotope ratios of fish otoliths. Science 155:1684-1685. Article

Gao, Y., and R. J. Beamish.

2003. Stable isotope variations in otoliths of Pacific halibut (Hippoglossus stenolepis) and indications for the possible 1990 regime shift. Fish. Res. 60:393-404. Article

Gao, Y. W., S. H. Joner, and G. G. Bargmann.

2001. Stable isotopic composition of otoliths in identification of spawning stocks of Pacific herring ( $\mathrm{Clu}$ pea pallasi) in Puget Sound. Can. J. Fish. Aquat. Sci. 58:2113-2120. Article

Gao, Y., G. G. Bargmann, U. Brand, and D. L. G. Noakes.

2005. Stable isotopic and trace elemental compositions of otoliths and the stock structure of Pacific cod, Gadus macrocephalus. Environ. Biol. Fish. 74:335-348. Article
González-Castro, M., G. J. Macchi, and M. B Cousseau.

2011. Studies on reproduction of the mullet Mugil platanus Günther, 1880 (Actinopterygii, Mugilidae) from the Mar Chiquita coastal lagoon, Argentina: similarities and differences with related species. Ital. J. Zool. 78:343353. Article

Ihssen, P. E., H. E. Booke, J. M. Casselman, J. M. McGlade, N. R. Payne, and F. M. Utter.

1981. Stock identification: materials and methods. Can. J. Fish. Aquat. Sci. 38:1838-1855. Article

Kalish, J. M.

1991. ${ }^{13} \mathrm{C}$ and ${ }^{18} \mathrm{O}$ isotopic disequilibrium in fish otoliths: metabolic and kinetic effects. Mar. Ecol. Prog. Ser. 75:191-203.

Kroopnick, P.

1980. The distribution of ${ }^{13} \mathrm{C}$ in the Atlantic Ocean. Earth Planet. Sci. Lett. 49:469-484. Article

Lemos, V. M., A. S. Varela Jr., P. R. Schwingel, J. H. Muelbert, and J. P. Vieira.

2014. Migration and reproductive biology of Mugil liza (Teleostei: Mugilidae) in south Brazil. J. Fish. Biol. 85:671-687. Article

Lemos, V. M., D. F. Ávila Troca, J. Pablo Castello, and J. P. Vieira.

2016. Tracking the southern Brazilian schools of Mugil liza during reproductive migration using VMS of purse seiners. Lat. Am. J. Aquat. Res. 44:238-246.

Mai, A. C. G., C. I. Miño, L. F. F. Marins, C. Monteiro-Neto, L. Miranda, P. R. Schwingel, V. M. Lemos, M. Gonzalez-Castro, J. P. Castello, and J. P. Vieira.

2014. Microsatellite variation and genetic structuring in Mugil liza (Teleostei: Mugilidae) populations from Argentina and Brazil. Estuar. Coast. Shelf Sci. 149:8086. Article

McConnaughey, T.

1989. ${ }^{13} \mathrm{C}$ and ${ }^{18} \mathrm{O}$ isotopic disequilibrium in biological carbonates: II. In vitro simulation of kinetic isotope effects. Geochim. Cosmochim. Acta 53:163-171. Article

Menezes, N. A., C. de Oliveira, and M. Nirchio.

2010. An old taxonomic dilemma: the identity of the western south Atlantic lebranche mullet (Teleostei: Perciformes: Mugilidae). Zootaxa 2519:59-68.

Michener, R. and K. Lajtha (eds.).

2007. Stable isotopes in ecology and environmental science, 2nd ed., 594 p. Blackwell Publishing, Maiden, MA.

Rijnsdorp, A. D.

1993. Fisheries as a large-scale experiment on life-history evolution: disentangling phenotypic and genetic effects in changes in maturation and reproduction of North Sea plaice, Pleuronectes platessa L. Oecologia 96:391-401. Article

Thorrold, S. R., S. E. Campana; C. M. Jones and P. K. Swart. 1997. Factors determining $\delta^{13} \mathrm{C}$ and $\delta^{18} \mathrm{O}$ fractionation in aragonite otoliths of marine fish. Geochim. Cosmochim. Acta 61:2909-2919.

Vieira, J. P.

1991. Juvenile mullets (Pisces: Mugilidae) in the estuary of Lagoa dos Patos, RS, Brazil. Copeia 1991:409-418. Article

Waples, R. S., A. E. Punt, and J. M. Cope.

2008. Integrating genetic data into management of marine resources: how can we do it better? Fish Fish. 9:423-449. Article 